\title{
THE IMPLEMENTATION OF HUMANISTIC LEARNING AT DARUL AMAN ISLAMIC HIGH SCHOOL IN ACEH BESAR
}

\section{Sulaiman}

(Sekolah Tinggi Agama Islam-Perguruan Tinggi Ilmu Al-Qur'an (STAI-PTIQ) Banda Aceh

E-mail: man_briwas@yahoo.com)

\begin{abstract}
$\overline{\text { Abstract: This article focuses on humanistic learning at an Islamic }}$ private school in Aceh. It uses qualitative descriptive method and takes seven subjects as the sample of the data. It shows that the humanistic learning in Darul Aman Private Madrasah Aliyah of Aceh Besar was implemented through three mechanisms. First, creating a humanist class situation, both physical and non-physical environment (socio-emotional), through a democratic approach. Second, employing a cooperative learning model as the basis of humanistic learning. Third, adopting an effective communication model in creating humanistic learning interactions. This involves cycle-models of communication and interaction of learning: one direction interaction (teacher-student), teacher-learners-learners (their feedback for teachers; students learn from each other) and multi-interaction of the teacher-learner, learner-teacher, learnerslearners (interaction in many directions). The implementation of humanistic learning at Darul Aman Private Madrasah Aliyah of Aceh Besar had a problem in the form of limited instructional media resources. Nevertheless, the overall learning process was humanist.
\end{abstract}

Keywords: Humanistic Learning, Situation of Humanistic Class, Cooperative Learning, and Pattern of Humanistic Learning Communication.

DOI: http://dx.doi.org/10.20414/ujis.v21i1.1161

\section{Introduction}

THE IMPLEMENTATION of humanistic learning in the madrasah is one of the efforts to create a humanistic learning system. Its application in educational institutions, including madrasah is the 
implication of the concept of humanistic education. Besides that, it would require the learning system which supports humanistic learning such as: the management of madrasah, the professional teachers, the participation of students, the conducive atmosphere of classroom, and the model of cooperative learning. Three approaches used in humanistic learning are dialogist, reflective, and expressive. ${ }^{1}$ The use of such approaches involves students' activities learning processes that encourage them to think critically.

The learning is the interaction process between students and teachers as well the environment and other supporting elements to change the learners' behavior towards the better. Learning is a process of interaction between students and their environment resulting in a change of better behavior. The main principle in the learning process is the process of involvement of all students' potential. This process requires a critical attitude of the teachers and the learners. ${ }^{2}$

One of the key successes in humanistic education is contingent upon learning process. This processes include a relatively permanent change in response potentiality which occurs as a result of reinforced practice and a change in human disposition or capability, which ca be retained, and which is not Simply ascribable to the process of growth. In this context, there are three principles that need to be considered. First, learn to make changes in the behavior of learners relatively permanent. Second, the students have the potential and capability that is the result of natural seeds to be cultivated. Third, the changes or achievement of the ideal quality that does not grow linearly aligned natural process of life; it must be cultivated and designed

${ }^{1}$ Muhammad Rohman and Sofan Amri, Manajemen Pendidikan Analisis Ksolusi terhadap Kinerja Manajemen Kelas dan Strategi Pengejaran yang Efektif (Jakarta: Prestasi Pustakaraya, 2012), 180.

2Dede Irawan Saputra, Ade Gafar Abdullah, and Dadang Lukman Hakim, "Pengembangan Model Evaluasi Pembelajaran Project Based Learning Berbasis Logika Fuzzy," Invotec 10 (2014): 13. 
to achieve the ideal quality. ${ }^{3}$ That is why the learning process has an important role in humanizing learners in education.

The educators should realize that every student has a unique potential. Bornok explained the differences of individual learner uniqueness in educational activities and learning must be looked after and valued by educators or teachers. ${ }^{4}$ Therefore, teachers can use the interesting, challenging, and fun methods of teaching to facilitate learning activity and mental activity of learners. Instead, educators in order to avoid the use of monotonous teaching methods and might not provide learning opportunities to students.

Monotonous teaching methods and teacher-centered are parts of the learning process that does not recognize the potential, uniqueness and capabilities of the learners. Therefore, the excessive use of such approaches to be avoided because it gives less opportunity to learners in playing an active role during the learning process. It is an unhumanistic learning practice in school.

Arbayah explains that education and learning in schools has been considered less democratic. It was showed by the lack of space for learners to use their imagination and creativity to show their existence with their own perspective. In fact, creativity and critical thinking skills are being capital for the child to be able to face challenges and more competitive. ${ }^{5}$ Further Arbayah explained that, criticisms and concerns are well-founded. The reality of the learning process that occurs in schools during this time did not provide opportunities for learners to develop their creativity and critical thinking skills. In addition, the learners are being the object of learning and they are positioned as the oppressed; those who do not know anything, people should be

${ }^{3}$ Siti Mumun Muniroh, "Penerapan Aliran Psikologi Humanistis dalam Proses Pembelajaran," Forum Tarbiyah 9 (2011): 46.

4Bornok Sinaga, "Pendidikan dan Pembelajaran Yang Demokratis dan Humanistis (Refleksi terhadap Paradigma, Proses, dan Produk Pendidikan Sebagai Dasar Revitalisasi Prinsip dan Nilai Pendidikan di Indonesia)," Majalah/Jurnal Generasi Kampus 5 (2012): 13.

5Arbayah, "Model Pembelajaran Humanistik," Dinamika Imu 13 (December 2013): 205. 
pitied and therefore should be stuffed and fed. Every day in the indoctrination and brainwashing continues happened to children. Children are considered as an empty vessel that is ready loaded with a variety of materials and interests for the sake of profit. Decades of children exposed to a dry recitation without any opportunity to develop exploration and creativity. ${ }^{6}$

The changes in teaching approaches from teacher centered to the student centered approach is a solution for the learning process is not oppressive to the uniqueness, potential, creativity thinking of learners, and the rights of study must-have that learners are democratic and humanist. Uci refers to Syifa'a Rahmahana Ratna explained; humanistic learning principles according to Carl Rogers include a passion for learning, meaningful learning, learning without threat, learn on their own initiative, and learn to change. ${ }^{7}$ That explanation hint learning process ideally accomplished with a democratic, without pressure, and engages learners optimally.

This research was conducted at Darul Aman Private Madrasah Aliyah of Aceh Besar. the aim of research is to see how the implementation of humanistic learning. The researcher was interested in this location because the learning process in this madrasah has stood as a humanist. In addition, there were found the obstacles that could hinder its implementation.

\section{Research Methodology}

This study is qualitative research with descriptive approach where the subjects in this study are six teachers and a headschool. The data were collected through triangulation (combined) and then analyzed inductively so that the research results further emphasize the significance than the generalization.

'Ibid.

${ }^{7}$ Uci Sanusi, "Pembelajaran dengan Pendekatan Humanstik (Penelitian Pada MTs Model Cigugur Kuningan)," Jurnal Pendidikan Agama Islam-Ta'lim 11 (2013): 129. 


\section{Grand Concept of Humanistic Learning Theory}

Arbayah explained that humanistic learning sees man as the free subject to determine the direction of his life. Humans are fully responsible for his life and also on the lives of others. Humanistic education emphasizing that education is first and foremost is how to establish communication and personal relationships between individuals as well between individuals and groups within the school community. This relationship is growing rapidly and produces result of education if it is based on the love between them. Persons only develop optimally and relatively unhindered if it is in an atmosphere of love, understanding heart as well as effective personal relationships. ${ }^{8}$

The onditioning of conducive learning situation and the use of cooperative learning to engage students in learning activities as an option for teachers in order to create a humanistic learning, which emphasizes the active learners in the learning process. It is as described Esti. Et al, that the humanistic approach to learning gives emphasize to familiarize brainstorming activity. ${ }^{9}$

The implementation of humanistic learning basically refers to humanistic learning theory developed by following figures:

First, Arthur Combs (1912-1999). A basic concept in learning which is used by Arthur is meaning (significance). This concept assumes that the student will grasp what she or he has learned if it has a meaning for her or his concern. Therefore, teachers also cannot and will not be able to force students to learn or study a preferred material that might not be relevant to students' life. Thus, the majority of cases on students who do not want and cannot master a subject matter or even students behaving badly (like truant or not following the learning process

8Arbayah, "Model Pembelajaran," 206.

${ }^{9}$ Esti Hayu Purnamaningsih, Asmadi Alsa, and Amitya Kumara, "Pengembangan Model Belajar Mengajar Mata Pelajaran IPS SD Untuk Mendukung Implementasi Kurikulum Berbasis Kompetensi di Propinsi Sumatera Selatan," Jurnal Psikologi 31 (2004): 16. 
in earnest) not because they are stupid, but they do not have a good reason to learn it. ${ }^{10}$

Second, Abraham H. Maslow. The development of Maslow's theory is based on the assumption that within the individual there is a positive effort of individuals to develop and strength to resist or reject the obstacles that may develop. He said that every person has the feeling of fear to try and develop, afraid to take chances, and the fear of losing what she or he already have. However, they also have incentives to accept their selves, advancing towards the proper functioning of all the skills and feeling confidence. Therefore, basically Maslow talked about all potential as a capital that has been owned and needs as a form of desires that encourage individuals share activity. ${ }^{11}$

Third, Carl Rogers. He was a humanistic psychologist who emphasized the need for mutual respect and without prejudice (between client and therapist) in helping people cope with the problems of life. Carl Rogers believed that the various inputs that exist in a person about his world according to his personal experience. These inputs unanimously pointed toward fulfilling his needs. Rogers asserted, in a personal self development will continue to strive for self-actualization, self maintenance, and self enhancement. ${ }^{12}$

The implications of humanistic learning theory in the learning process lies in the recognition of the actualization of students as active learning actors. The impact of this theory then emerged cooperative learning model that is considered to be more democratic and humanizing learners to develop in accordance with its potential.

\section{Creating a Classroom Situation of Humanistic On Private Madrasah Aliyah Darul Aman Aceh Besar}

The humanistic classroom situations can be built by creating an enabling environment, both physical and nonphysical. Mulyasa explained such situations, such as: safe, comfortable,

10Muhammad Irham and Novan Ardy Wiyani, Psikologi Pendidikan (Yogyakarta: Ar-Ruzz Media, 2013), 190.

11Ibid., 192.

12Arbayah, "Model Pembelajaran,” 207. 
and orderly, combined with optimism and high expectations of the entire school community, school health, and studentcentered activities is a climate that can turn lust, passion, and enthusiasm for learning. That atmosphere will encourage the creation of learning communities in schools, because a conducive learning climate are the backbone and driving factors that can be the main attraction for the learning process, rather less pleasant learning climate will lead to burnout and boredom. ${ }^{13}$

The learning process is operationally implemented in the classroom. For that, teachers are expected to manage a classroom situation in order to support the learning process. Teachers are required to have skills in creating classroom situations that enable learners perform conducive learning activities.

Didi refers to the opinion of John I. Bolla explained that classroom management is a skill that must be held by teachers; whereas the definition of classroom management is the skills of teachers to create and maintain optimal learning conditions and skills to restore the optimal learning conditions, if there are dependents of the learning process both small disturbance and temporary disruptions in the learning process and teachers act to restore to optimal learning situation then that included classroom discipline action. ${ }^{14}$

The almost same phrase are also described Moh. Uzer Usman in Novan that managing a classroom is teacher skills to create and maintain an optimal learning conditions and restore it if something bad happens in the teaching-learning process. ${ }^{15}$

Novan further added that classroom management skills serve as a preparation for the teacher as learning leader in the classroom. In the context of the classroom a teacher also acts as a learning manager that manages the classroom as a learning

${ }^{13}$ E. Mulyasa, Manajemen Pendidikan Karakter (Jakarta: Bumi Aksara, 2011), 19.

${ }^{14}$ Didi Supriadi and Deni Darmawan, Komunikasi Pembelajaran (Bandung: Remaja Rosdakarya, 2012), 162.

${ }^{15}$ Novan Ardy Wiyani, Manajemen Kelas Teori dan Aplikasi untuk Menciptakan Kelas yang Kondusif (Yogyakarta: Ar-Ruzz Media, 2013), 43. 
environment as well the aspects of school environment that need to be organized. ${ }^{16}$

Teachers are managers who are responsible for conducive classroom situations to support and facilitate the activities of learners. The good situation in classrom is a hallmark of humanistic implementation. Humanistic class situation is a class that facilitates optimal learning activities of learners, challenging class, a class that can stimulate learners to learn, as well as providing a sense of security and satisfaction of learning to the learners.

Such a class is important part that should be created by teachers to create an atmosphere of humanistic learning. Classroom situation both physical and non-physical (socioemotional) are the optimal situation class that supports the humanistic learning. These were described by Irham. Et al, that creating a physical environment that is positive and fun learning include spatial and other conditions; posing socio-emotional environment that is fun for all students. ${ }^{17}$ Therefore, teachers are expected to have the skills associated with the creation of the humanist classroom situation.

In general, the effort to create humanistic classroom situation on Darul Aman Private Madrasah Aliyahof Aceh Besar was done through the management of physical and nonphysical grade class (socio-emotional). Associated with these two, described below:

First, the management of the physical environment class is part of the efforts that was made by teachers to create humanistic learning situation and facilitate the activities of learners in the classroom, which include: (1) a table setting of learners, (2) the board, (3) a closet inventory, and (4) others. ${ }^{18}$ As stated by teachers, that the efforts made to create a humane learning are done through the physical arrangement of the

16Ibid.

17Irham and Wiyani, Psikologi Pendidikan, 192.

${ }^{18}$ Interview with Physics Teacher of MAS Darul Aman Aceh Besar, November 12, 2016. 
classroom environment. ${ }^{19}$ The same explanation was also described by other four teachers. Furthermore, such information was also confirmed by the headmaster that one of the steps taken by teachers to create humane learning situations is done through the physical arrangement of the classroom environment. ${ }^{20}$

The physical environment of classroom management effectively can improve the activity of learners. Darmadi explained that the arrangement of effective physical environment greatly affects the base of learners. ${ }^{21}$ The situation of the physical environment in the classroom of Darul Aman Private Madrasah Aliyah of Aceh Besar seems look positive, it means that the class situation is already well to support the learning process. Furthermore, the students are very enthusiastic in their learning activities.

The physical conditions of class are very decisive toward the improving learning activities of students, so that this aspect is an important concern of Darul Aman Private Madrasah Aliyah of Aceh Besar. Various attempts were also done to eager the spirit of learners, such as painting classrooms. Energetic class color can also encourage learners' spirit of study. This is as Mulyasa explained that, an expert on the psychological especially Ecological has been getting research findings that color management directly affects the atmosphere of life, bright colors tend to imply cheerfulness and optimalistic soul atmosphere, while the use of colors dingy will give the opposite effect. ${ }^{22}$ For that reason, the teacher and the leader of Darul Aman Private Madrasah Aliyah paint the classrooms, so it can reflected a humanist classroom.

${ }^{19}$ Interview with Physics Teacher of MAS Darul Aman Aceh Besar, November 12, 2016.

${ }^{20}$ Interview with Headmaster MAS Darul Aman Aceh Besar, November $11,2016$.

${ }^{21}$ Hamid Darmadi, Keterampilan Dasar Mengajar (Bandung: Alfabeta, 2012), 7 .

${ }^{22}$ E. Mulyasa, Pengembangan dan Implementasi Kurikulum 2013 (Bandung: Remaja Rosdakarya Offset, 2014), 53. 
Second, nonphysical class (socio-emotional). An effective interpersonal relationship among the class members is the crucial aspect of humanist classroom. Salman explained that a class can be managed efficiently by teachers to foster the good relationships with learners. The approach that is based on the good relations between teachers and learners is called socioemotional approach. In addition, He thought that the classroom atmosphere will be more conducive if the relation among students can be established. However, in order to realize this, the teacher must be able to establish communication and positive interaction with learners first. In this case, the teacher is the key to the development of relations, both between themselves with learners and between learners with learners. ${ }^{23}$

Based on the explanation above, teachers are required to have the skills in designing a conducive classroom situation through the maintenance of good relations between teachers and learners, learners with fellow learners. The positive socioemosial relations in classroom can be realized by teachers with a democratic approach, being open to learners, understanding to each other, protecting and providing the opportunity for learners to express their skills in the classroom.

The teacher made an effort to create a humanist situation in class during the learning process by building up an effective socio-emotional relationship. ${ }^{24}$ The phrase is almost equally well explained by mathematics teachers that the positive socioemotional relationship can build up the conducive situation in class. ${ }^{25}$ The information is supported also by the headmaster that such situation boost the learning process that done by teacher though creating inter-personal interaction in the classroom, using democratic approach and uswatun basanah. ${ }^{26}$

23Salman Rusydie, Prinsip-Prinsip Manajemen Kelas (Yogyakarta: Diva Press, 2011), 54.

${ }^{24}$ Interview with Arabic Language Teacher of MAS Darul Aman Aceh Besar, November 11, 2016.

25Interview with Mathematics Teacher of MAS Darul Aman Aceh Besar, November 11, 2016.

26Interview with Headmaster of MAS Darul Aman Aceh Besar, November 11, 2016. 
Likewise, the observation proved that democratic approach and uswatun hasanah were showed by teacher both in the learning process and out of the school hours. ${ }^{27}$

According to the interviews with teachers, head Madrasah, and the observations which were conducted at Darul Aman Private Madrasah Aliyah Aceh Besar, it can be conclude that the democratic approach and uswatun hasanah are two ways for teacher to create a humanistic classroom situation.

The learning process in this madrasah can be classified as humanists because of the interaction among class member is good. The teacher's attitude is open, fair, tolerant and polite in providing guidance to the learners in the learning process.

The opennes, tolerance and sincerity are some approaches used in Darul Aman Private Madrasah Aliyah of Aceh Besar to perform the humanist class. This is in line with the opinion of Carl. A Rogers in Rohani which stated that, the importance of teachers being sincere in front of learners (roalness, genueness, and congruence), accepting and appreciating learners as human beings (acceptance, prizing, caring and trust), and understanding the learners from the point of view of the learners themselves (emphatio understanding). ${ }^{28}$

Besides that, the democratic atmosphere is an important part of creating humanistic classroom situation. This aspect become a concern of teachers at Darul Aman Private madrasah Aliyah in Aceh Besar. The democratic classroom atmosphere aims to form the responsible and independent students. According to Rudolf Dreikurs in Rohani, the importance of classroom democratic processes in which students learn the responsibility, through the opportunity to take responsibility; man needs to wisely take a decision on the side given the opportunity. Bearing the consequences of his actions. ${ }^{29}$ Thus, the classroom atmosphere is humanistic.

${ }^{27}$ Observation of the Learning Process, November 11, 2016.

${ }^{28}$ Ahmad Rohani, Pengelolaan Pengajaran (Jakarta: Renaka Cipta, 2004), 173.

29Ibid., 174. 


\section{The Application of Humanistic learning Model at Darul Aman Islamic Senior High School of Aceh Besar}

Learning is an active process that requires strategy and guidance. Sanjaya explained that learning is not memorizing facts or information. Learning is act; gain particular experience in accordance with the competence to be achieved. Therefore, the learning strategies should encourage the activity of learners. ${ }^{30}$ The same explanation also described Jerome Brunner in Trianto that learning is an active process in which learners construct new knowledge based on the experience or knowledge that he already owns. ${ }^{31}$ Then, teachers are expected to use learningoriented approach in order to become active learners teaching priorities.

The cooperative learning can be used by teachers to develop cooperative behavior and effective learning interactions of learners. Furthermore, cooperative learning can also develop students' academic ability and stimulates the creativity as well to form new ideas and learners can compete humanist. Lestari explained that the cooperative learning is one of learning model that engage learners. ${ }^{32}$ In line with these explanations, Ali explained that the implementation of humanistic learning can be done by providing learning opportunities to learners. ${ }^{33}$ The application of this model has implications for improving the performance of learners.

The cooperative learning and democratic process are characteristic of humanistic learning that emphasizes the involvement of the students actively in learning without neglecting the ability and the uniqueness of learners, which implies humanistic interaction. This refers to the views of Paulo

30Wina Sanjaya, Pembelajaran dalam Implementasi Kurikulum Berbasis Kompetensi (Jakarta: Prenada Media Group, 2008), 103.

31'Trianto, Mendesain Model Pembelajaran Inovatif-Progresif (Jakarta: Kencana Prenada Media Group, 2013), 15.

32R. Lestari and S. Linuwih, "Penerapan Model Pembelajaran Kooperatif Tipe Pair Checks Pemecahan Masalah untuk Meningkatkan Social Skill Siswa," Jurnal Pendidikan Fisika Indonesia 8 (2012): 191.

${ }^{33} \mathrm{Ali}$ Mahrus, "Mengatasi Kesulitan Belajar Melalui Klinik Pembelajaran: Studi Analisis pada Mata Pelajaran Fisika," Konseling Religi Jurnal Bimbingan Konseling Islam 4 (2013): 281. 
Freire in Ahmad, in the term of Paulo Freire, "humanistic interaction" is in line with the concept of education (read: the learning process) "facing problem", which seeks to make the learners as a humanist; that can develop the ability to understand himself and his life critically; which confirms learners as beings who are in the process of becoming towards perfection in reality that was never completed. ${ }^{34}$

Furthermore, Ahmad explained, the concept of education "facing problems" proposed by Freire as opposed to the concept of education (learning) "style bank" (banking system), in which the reality has been formed learners as 'mute' human, uncommunicative; provide passive space to the students, only receiving, recording and storing information subjects, thus giving dehumanizing power on the learner. ${ }^{35}$ This case then being the reason why there is resistance to learning-oriented teacher (teacher centered), which considers students as an object.

Based on the information obtained during the research activity, it confirms that the teacher in Darul Aman Private Madrasah Aliyah of Aceh Besar applied cooperative learning as the effort to engage student's motivation and its implementation has a positive impact on the interest of learners. It is relevant to the previous research in this madrasah (school), which stated that the implementation of cooperative learning in teaching Fiqib can enhance the spirit of learning. ${ }^{36}$ Another implication of the implementation of cooperative learning in teaching Fiqib is that learners can learn together and exchanging opinions and practice critical thinking. The same argument was given by the teacher of the Qur'an and Hadith. This is part of the learning humanistic process. ${ }^{37}$

34Ahmad Ta'rifin, "Membangun Interaksi Humanistik dalam Proses Pembelajaran," Forum Tarbiyah 7, no. 1 (June 2009): 105.

${ }^{35}$ Ibid.

36Interview with Fiqh Teacher of MAS Darul Aman Aceh Besar, November 12, 2016.

${ }^{37}$ Interview with Teacher of Al-Qur'an and Hadith of MAS Darul Aman Aceh Besar, November 12, 2016. 
In addition, teachers who teach in this madrasab explained that, the uses of cooperative learning can also train and shape social life of learners. Through the group discussion phase, students were trained being responsible to their groups and working together.

There were various cooperative learning models that are implemented by teachers to create the humanist learning at Darul Aman Private Madrasah Aliyah of Aceh Besar, such as: (1) cooperative Student Teams Achievement (STAD), (2) Expert Team (Jigsaw), (3) Think Pair (SPS), and (4) Numbered Head Together (NHT). ${ }^{38}$

The explanation about the use of several models of cooperative learning from the headmaster was different from the results of observation. It proved that only three of five teachers-that were observed-who performed jigsaw model. ${ }^{39}$

The use of cooperative learning model at Darul Aman Private Madrasah Aliyah of Aceh Besar as mentioned above, aims to involve students actively in the learning process. The students are trained to skillfully argued, work (skill), and various other skills in line with developing their ability. That is part of the urgency of using cooperative learning to build a humanistic learning process. It is as described by Asri that learning strategies; integrated learning, cooperative learning, learning is grounded in the beginning concept of students, through a portfolio assessment, reflection, all this is highly recommended in humanist learning strategies. ${ }^{40}$

The next step to support the learning process at Darul Aman Private Madrasah Aliyah of Aceh Besar is the professional development of teachers, particularly in relating of teaching skills and the use of cooperative learning. ${ }^{41}$ As the consequence,

38Interview with Headmaster MAS Darul Aman Aceh Besar, November $11,2016$.

${ }^{39}$ Observation of the Learning Process, November 11 and 12, 2016.

${ }^{40}$ C. Asri Budiningsih, "Strategi Pembelajaran Nilai Yang Humanis," Dinamika Pendidikan, Majalah Ilmu Pendidikan No. 02/TH.XVII/Oktober 2010, n.d., 11.

${ }^{41}$ Interview with Headmaster MAS Darul Aman Aceh Besar, November $11,2016$. 
the headschool conducted the teaching skills development to support the teachers in implementing cooperative learning.

\section{Communication Patterns of Effective Learning In Creating Humanistic Learning Interactions in Darul Aman Private Madrasah Aliyah of Aceh Besar}

Rosyada explained that teachers act as communicators in learning. ${ }^{42}$ Then, they are required to improve the communication skills effectively in the classroom.

In fact, sometimes we find the failures in learning process. This is caused by the ineffective communication system in established by teacher, so there is no interaction in the learning process. To handle the problem, teacher should build the interactive communication system in which the learning process will improve significantly. For that, Tutut explained, the teacher in order to develop effective communication patterns in the learning process. ${ }^{43}$

Communication pattern in this research is defined as the interaction between teachers and learners, learners to learners during the learning process. It is crucial to create interactive and effective learning considering that the learning activities are based commonly on the interaction among the class member.

It is used by teachers to build a humanistic learning which has a positive benefit to the independence of learners and activeness in learning. Nova. Et al, explained that the more students are involved in the various activities, indicating that she or he has learned a high degree of independence. ${ }^{44}$

The Physics teacher who taught at Darul Aman Private Madrasah Aliyah of Aceh Besar stated that the efforts to build interactive learning and humanist can be done using a variety of

42Dede Rosyada, Paradigma Pendidikan Demokratis (Jakarta: Kencana Premedia Group, 2007), 146.

43Tutut Handayani, "Membangun Komunikasi Efektif Untuk Meningkatkan Kualitas dalam Proses Belajar Mengajar," Ta'dib 16 (2011): 249.

${ }^{44 N o v a ~ F a h r a d i n a, ~ B a n s u ~ I . ~ A n s a r i, ~ a n d ~ S a i m a n, ~ " P e n i n g k a t a n ~}$ Kemampuan Komunikasi Matematis dan Kemandirian Belajar Siswa SMP dengan Menggunakan Model Investigasi Kelompok," Jurnal Didaktik Matematika 1 (2014): 56. 
communication patterns. ${ }^{45}$ Its implementation has a positive impact on the motivation of learners. The situation can be seen from the aspect of confidence and active learners in learning activities. Furthermore, according to information from the head of Madrasah that applying many styles of communication model can prevent the saturation of learning and building the most active learning environment. 46

The explanation above is in line with the statement of Sulaiman that teachers can build the communication system through a variety of interaction patterns in order to prevent boredom of learners in the classroom. ${ }^{47}$ Based on the observation, there are three learning communication patterns used by teachers in Darul Aman Private Madrasah Aliyah of Aceh Besar to build a humanistic learning, as can be seen in the following description:

1) One-way learning interactions (teacher-student),

2) Interaction of teacher-learners-learners (their feedback for teachers; students learn from each others), and

3) The pattern of teacher-learner interaction, learner-teacher, learner-learner (the interaction of many directions). ${ }^{48}$

The use of various interactive patterns in Darul Aman Private Madrasah Aliyah of Aceh Besar is part of the strategy pursued to involve learners actively in the learning process as well to build an atmosphere of effective and fun learning. Mulyasa refers to the opinion of Sudjana explained that the involvement of learners is very important and it determines the success of learning. ${ }^{49}$ The use of learning interaction pattern is

${ }^{45}$ Interview with Physics Teacher of MAS Darul Aman Aceh Besar, November 12, 2016.

46Interview with Headmaster MAS Darul Aman Aceh Besar, November 11, 2016.

${ }^{47}$ Sulaiman, "Menjadi Guru PAI yang Dirindukan Peserta Didik dalam Kelas" (presented at the $1^{\text {st }}$ Annual Internasional Seminar on Education, Fakultas of Tarbiyah and Teacher's Training State Islamic University of ArRaniry Banda Aceh, 2015), 96.

${ }^{48}$ Observation of the Learning Process, November 11 and 12, 2016.

${ }^{49}$ Mulyasa, Pengembangan dan, 123. 
very helpful to encourage the participation of learners in the humanistic learning.

In relating to that, Djamarah refers to the views of Moh. Uzer Usman, said there are five patterns of interaction, these are:

1) The pattern of teacher-students (communication as action / one way).

2) The pattern of teacher-students-teachers (their feedback / feedback for teachers; there is no interaction between students; communication as interaction).

3) The pattern of teacher-students-students (their feedback for teachers; students learn from each other).

4) The pattern of teacher-students, students-teachers, students-students (optimal interaction between teachers and students and between students with students; communication as a transaction; multi-way).

5) The circular pattern (every student gets a turn to express speech or answers; not allowed to speak twice when each of the students does not get a turn)..$^{50}$

Professionalism of teachers is very important in creating an atmosphere of humanistic learning. The learning patterns can be used by teachers to build interactive learning environment, effective, and fun. This is part of the humanistic learning process, namely humanizing learning without neglecting the uniqueness of learners built with the communication patterns approach.

\section{The obstacles of Humanistic Learning Implementation at Darul Aman Private Madrasah Aliyah of Aceh Besar}

The implementation of humanistic learning will be done optimally if it is supported by the device or effective learning media. Nowadays, there are still found in schools some teachers are teaching without using the relevant media. Nani refer to the explanation of Kamil that the obstacle of learning usually come from the learners and learning resources or from inadequate

50Syaiful Bahri Djamarah, Guru \& Anak Didik dalam Interaksi Edukatif (Jakarta: Rineka Cipta, 2010), 13-14. 
facilities and infrastructure. ${ }^{51}$ The limitations of learning resources give an impact on the effectiveness of humanistic learning process.

The implementation of humanistic learning at Darul Aman Private Madrasah Aliyah Aceh Besar still faces the obstacles. One of them is the availability of teaching and learning media. The learning process takes place without any media tools adequate learning. The only available media in madrasab is one unit Laptop. ${ }^{52}$

To overcome the obstacles, most of the teacher prepared the learning media by themselves. This information was obtained from mathematics, physics, and fikih teachers. The efforts are made to support the learning process and optimize the humanistic engagement of learners, so that the learning objectives can be achieved. It is, as described Suryosubroto that, tools or teaching media serves to assist the teaching process so that objectives can be achieved with the best achievement. ${ }^{53}$

Further, the headschool added that the use of media in the learning process is basically aimed at creating the learning process more effective, interesting, and fun, and engage learners optimally engage in the learning process. Then, the use of media in the learning process is also beneficial to eliminate saturation learn. ${ }^{54}$

Ali Muhson quoting from Eyler and Giles's research in Widharyanto proved the effectiveness of learning is influenced by media used by teachers. ${ }^{55}$ Instructional media has an important position to support the interactive, innovative, and funlearning process as the hallmark of humanistic learning process.

${ }^{51}$ Neni Ana Nofita, "Hambatan-hambatan Warga Belajar dalam Proses Pembelajaran Program Paket C di Kecamatan Pancung Soal Kabupaten Pesisir Selatan," Spektrum PLS 1 (2013): 150.

52Observation of the Learning Process, November 12, 2016.

53B. Suryosubroto, Proses Belajar Mengajar di Sekolah (Jakarta: Renika Cipta, 2009), 164.

54Interview with Headmaster MAS Darul Aman Aceh Besar, November 11, 2016.

${ }^{55}$ Ali Muhson, "Pengembangan Media Pembelajaran Berbasis Teknologi Informasi," Jurnal Pendidikan Akuntansi Indonesia 8 (2010): 2. 
Related to the role of media in the implementation of the humanistic learning process based on various information obtained by the teachers stated that the role of media is very strategic to overcome any shortcomings in the process of learning, such as teacher's explanations are unclear can be resolved by the media and create more interactive learning and can improve the quality of learning. This information is in line with the explanation of Edgar Dale in Sigit Prasetyo that the media have utility as follows: clarify the message that is not too verbalistis, overcome the limitations of space, time, energy and power of the senses, excite the learning, the interaction directly linking the pupils to learning resources, allowing children to do self-learning according to their talents and visual, auditor and kinesthetic abilities, give the same stimuli, likening the experience and perceptions of the same cause ". ${ }^{56}$

Although the implementation of humanistic learning process at Darul Aman Private Madrasah Aliyah of Aceh Besar had some obstacles, but generally the learning process can be done effectively, because the limitation of instructional media can be handled by teachers through initiative idea.

\section{Conclusion}

The humanistic learning refers to the concept of humanistic education is based on a theory developed by Arthur Combs, Abraham H. Maslow, Carl Rogers, and Paulo Freire. The basic principle of humanistic learning is providing the confidence and opportunities to students in developing their uniqueness and potential. It can be said that, the humanistic learning process is based on student-centered approach to engage active learners optimally.

The humanistic learning in the Private Aliyah Madrasah Darul Aman Aceh Besar was implemented through three approaches, these are: First, creating a humanist situation in class both physical and non-physical environment (socio-emotional) via democratic approach. Second, the humanistic learning process

56Joni Purwono, "Penggunaan Media Audio-Visual Pada Mata Pelajaran Ilmu Pengetahuan Alam di Sekolah Menengah Pertama Negeri 1 Pacitan," Jurnal Teknologi Pendidikan dan Pembelajaran 2 (2014): 129. 
is built on the cooperative learning model to engage learners activities. Third, three patterns of interaction aimed to improve the communication activities among class members, namely: (1) the interaction patterns of learning in one direction (teacherstudent), (2) interaction pattern of teacher-learners-learners (their feedback for teachers; students learn from each other), and (3) the interaction pattern of teacher-learner, learnerteacher, learners-learners (interaction in many directions)

The implementation of humanistic learning at Darul Aman Private Madrasah Aliyah of Aceh Besar did not optimal yet; this condition was caused by the unavailability of instructional media to support the learning process. However, some brilliant teachers solved the problem by constructing learning media on their own to create an effective, interactive, fun and humanist learning.

\section{Reference}

Arbayah. "Model Pembelajaran Humanistik." Dinamika Ilmu 13 (December 2013).

Budiningsih, C. Asri. "Strategi Pembelajaran Nilai Yang Humanis." Dinamika Pendidikan, Majalah Imu Pendidikan No. 02/TH.XVII/Ok.tober 2010, n.d.

Darmadi, Hamid. Keterampilan Dasar Mengajar. Bandung: Alfabeta, 2012.

Djamarah, Syaiful Bahri. Guru \& Anak Didik dalam Interaksi Edukatif. Jakarta: Rineka Cipta, 2010.

Fahradina, Nova, Bansu I. Ansari, and Saiman. "Peningkatan Kemampuan Komunikasi Matematis dan Kemandirian

Belajar Siswa SMP dengan Menggunakan Model Investigasi Kelompok." Jurnal Didaktik Matematika 1 (2014): 54-64.

Handayani, Tutut. "Membangun Komunikasi Efektif Untuk Meningkatkan Kualitas dalam Proses Belajar Mengajar." Ta'dib 16 (2011): 273-303.

Irham, Muhammad, and Novan Ardy Wiyani. Psikologi Pendidikan. Yogyakarta: Ar-Ruzz Media, 2013.

Lestari, R., and S. Linuwih. "Penerapan Model Pembelajaran Kooperatif Tipe Pair Checks Pemecahan Masalah untuk 
Meningkatkan Social Skill Siswa." Jurnal Pendidikan Fisika Indonesia 8 (2012): 190-194.

Mahrus, Ali. "Mengatasi Kesulitan Belajar Melalui Klinik Pembelajaran: Studi Analisis pada Mata Pelajaran Fisika." Konseling Religi Jurnal Bimbingan Konseling Islam 4 (2013): 263294.

Muhson, Ali. "Pengembangan Media Pembelajaran Berbasis Teknologi Informasi." Jurnal Pendidikan Akuntansi Indonesia 8 (2010).

Mulyasa, E. Manajemen Pendidikan Karakter. Jakarta: Bumi Aksara, 2011.

. Pengembangan dan Implementasi Kurikulum 2013. Bandung: Remaja Rosdakarya Offset, 2014.

Muniroh, Siti Mumun. "Penerapan Aliran Psikologi Humanistis dalam Proses Pembelajaran." Forum Tarbiyah 9 (2011): 4561.

Nofita, Neni Ana. "Hambatan-hambatan Warga Belajar dalam Proses Pembelajaran Program Paket C di Kecamatan Pancung Soal Kabupaten Pesisir Selatan." Spektrum PLS 1 (2013): 144-160.

Purnamaningsih, Esti Hayu, Asmadi Alsa, and Amitya Kumara. "Pengembangan Model Belajar Mengajar Mata Pelajaran IPS SD Untuk Mendukung Implementasi Kurikulum Berbasis Kompetensi di Propinsi Sumatera Selatan." Jurnal Psikologi 31 (2004): 15-27.

Purwono, Joni. "Penggunaan Media Audio-Visual Pada Mata Pelajaran Ilmu Pengetahuan Alam di Sekolah Menengah Pertama Negeri 1 Pacitan." Jurnal Teknologi Pendidikan dan Pembelajaran 2 (2014): 127-144.

Rohani, Ahmad. Pengelolaan Pengajaran. Jakarta: Renaka Cipta, 2004.

Rohman, Muhammad, and Sofan Amri. Manajemen Pendidikan Analisis Ksolusi terhadap Kinerja Manajemen Kelas dan Strategi Pengejaran yang Efektif. Jakarta: Prestasi Pustakaraya, 2012.

Rosyada, Dede. Paradigma Pendidikan Demokratis. Jakarta: Kencana Premedia Group, 2007.

Rusydie, Salman. Prinsip-Prinsip Manajemen Kelas. Yogyakarta: Diva Press, 2011. 
Sanjaya, Wina. Pembelajaran dalam Implementasi Kurikulum Berbasis Kompetensi. Jakarta: Prenada Media Group, 2008.

Sanusi, Uci. "Pembelajaran dengan Pendekatan Humanstik (Penelitian Pada MTs Model Cigugur Kuningan)." Jurnal Pendidikan Agama Islam-Ta'lim 11 (2013): 123-142.

Saputra, Dede Irawan, Ade Gafar Abdullah, and Dadang Lukman Hakim. "Pengembangan Model Evaluasi Pembelajaran Project Based Learning Berbasis Logika Fuzzy." Invotec 10 (2014): 13-34.

Sinaga, Bornok. "Pendidikan dan Pembelajaran Yang Demokratis dan Humanistis (Refleksi terhadap Paradigma, Proses, dan Produk Pendidikan Sebagai Dasar Revitalisasi Prinsip dan Nilai Pendidikan di Indonesia)." Majalab/Jurnal Generasi Kampus 5 (2012).

Sulaiman. "Menjadi Guru PAI yang Dirindukan Peserta Didik dalam Kelas." Fakultas of Tarbiyah and Teacher's Training State Islamic University of Ar-Raniry Banda Aceh, 2015.

Supriadi, Didi, and Deni Darmawan. Komunikasi Pembelajaran. Bandung: Remaja Rosdakarya, 2012.

Suryosubroto, B. Proses Belajar Mengajar di Sekolah. Jakarta: Renika Cipta, 2009.

Ta'rifin, Ahmad. "Membangun Interaksi Humanistik dalam Proses Pembelajaran." Forum Tarbiyah 7, no. 1 (June 2009): 99-114.

Trianto. Mendesain Model Pembelajaran Inovatif-Progresif. Jakarta:

Kencana Prenada Media Group, 2013.

Wiyani, Novan Ardy. Manajemen Kelas Teori dan Aplikasi untuk Menciptakan Kelas yang Kondusif. Yogyakarta: Ar-Ruzz Media, 2013. 